\title{
Canciones de boda en la provincia de Guadalajara. Su proceso de creación y la dinámica de cambio
}

Es algo aceptado que el cambio -al menos en un nivel superestructural- es una de las características de la cultura y, sin embargo, no siempre se ha tenido en cuenta este hecho al tratar de la cultura popular, en especial la del ámbito rural, a la que se ha considerado arcaica, estática y ahistórica. En consecuencia, y como parte de dicha cultura, se han aplicado los mismos atributos a sus manifestaciones musicales, apreciadas fundamentalmente en su aspecto formal. Pero si bien es cierto que muchas de las mutaciones sucedidas en sus repertorios, al ser asimilados a un «estilo tradicional» son difíciles de detectar desde una perspectiva sincrónica, es posible percibirlas con más claridad al ser analizadas teniendo en cuenta la profundidad histórica que se presupone a todo cambio.

El cancionero popular tiene su razón de ser en el marco de unas determinadas actividades humanas y es interpretado, en general, por un grupo social concreto dentro de la comunidad en la que existe. Su carácter «funcional» hace que su temática sea variada, aunque no siempre está directamente relacionada con la acción a la que va unida. Por ello, si evoluciona la sociedad que la produce, su estructura, sus actividades, su mentalidad, probablemente evolucionará su música o las manifestaciones sociales que la soportan.

La provincia de Guadalajara es una de las de más baja densidad de población del país. La mayor parte de ésta se concentra en la capital, mientras que el resto se distribuye en localidades muy pequeñas en donde los habitantes tienen una media de edad muy elevada. La economía y el tipo de habitat de la provincia son de índole rural aunque la emigración y la mecanización de los trabajos agrícolas, a los que se dedican las pocas personas que quedan en activo, han supuesto una profunda alteración de las estructuras sociales que la caracterizaban hace unas décadas. Así, los cantos de boda que vamos a analizar, recopilados durante 1985 y 1986, al tiempo que se elaboraba un catálogo de música popular tradicional de la provincia, dejaron de interpretarse de forma habitul hace entre quince y treinta años y actualmente se conservan escritos en cuadernos, junto con otros cantos, o bien en la memoria de los intérpretes, creadores o personas que los escucharon en repetidas ocasiones en sus vidas. 

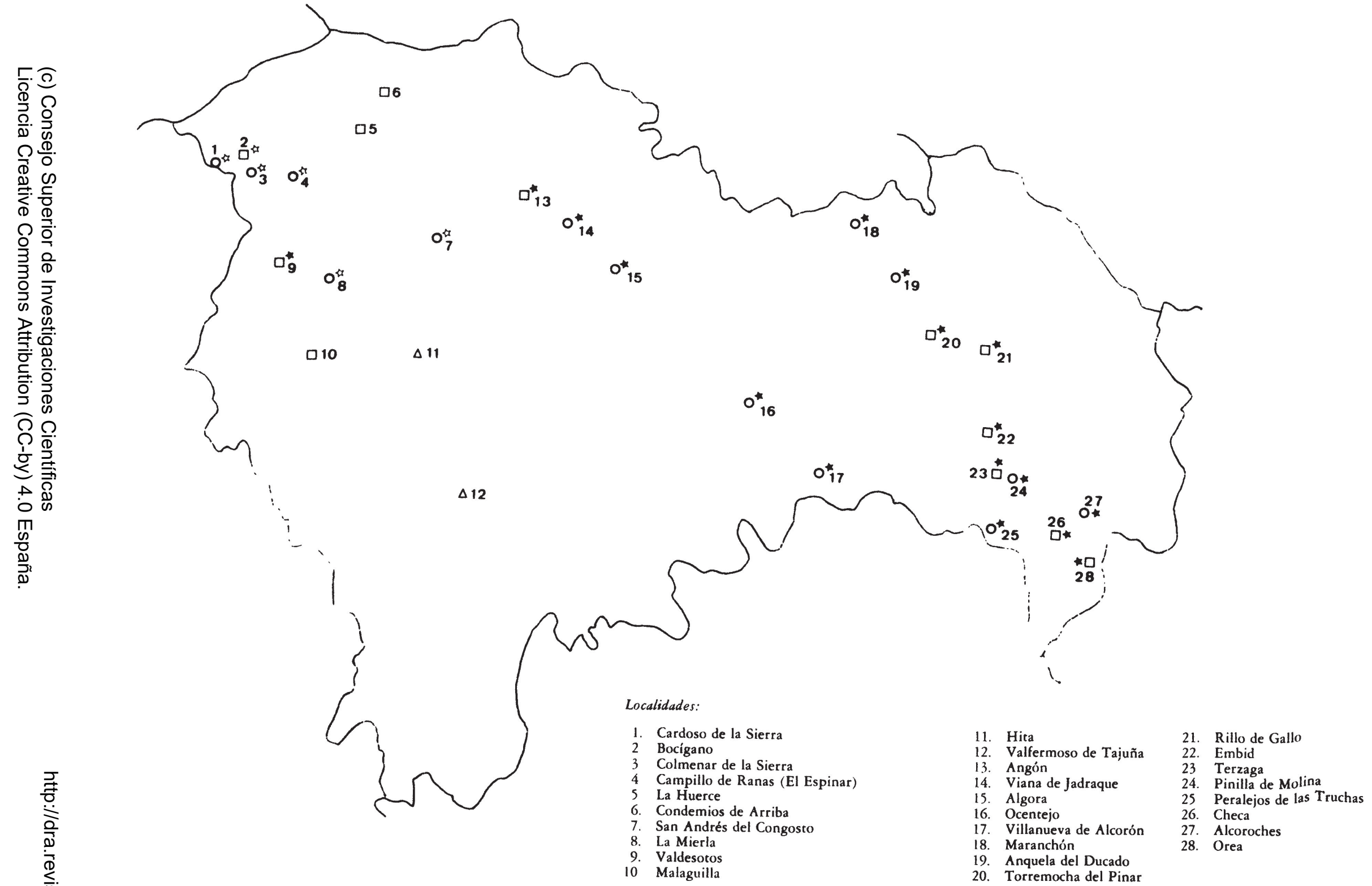

Fig. I.-Datos sobre canciones de boda recogidos en la provincia de Guadalajara.

Canciones grabadas durante el trabajo de campo.

Datos procedentes de la encuesta escrita y de informaciones orales (Canciones no grabadas)

$\triangle$ Datos obtenidos de A. Aragonés Subero: Danzas, rondas y música popular en la provincia de Guadalajara.

Canto específico para la ocasión (Despedida de novios).

$\star$ Ronda de jotas. 
Al lado de este tipo de cambio radical - la pérdida de funcionalidad y de significación social- en el repertorio musical de una zona concreta, existen otros más graduales, lentas variaciones que pueden no ser percibidas como cambios. En este sentido, John Blacking establece una interesante distinción entre el cambio de un sistema musical por otro y el cambio producido dentro de un sistema musical (cambios en los sonidos, en el estilo) ${ }^{1}$. Distinción que, según el citado autor, sólo puede hacerse relacionando las variaciones en el proceso y en los productos musicales con la percepción y los modelos de interacción de quienes utilizan la música, pues el cambio musical no tiene lugar en un vacío social. Por esto considera importante tener en cuenta también el punto de vista de la comunidad que produce y consume la música.

Dado que la música de estos cantos se ha perdido en gran parte, al no ser interpretada desde hace años y no existir grabaciones de diferentes épocas, es difícil analizar la evolución de los aspectos puramente musicales. Sin embargo, hemos podido obtener datos que nos permitieran conocer el proceso de creación y evaluar la transformación que se produce en los repertorios concretos de distintas localidades de la provincia de Guadalajara, analizando la estructura de los textos de las canciones y su funcionamiento, así como su funcionalidad y adaptación al contexto cultural. Una aproximación a la música como cultura nos llevará a acercarnos a conocer el comportamiento social e individual con respecto a ella y a saber de qué forma se manifiesta éste en la música. Entendemos los textos como un discurso que la comunidad que los acepta como suyos, hace de sí misma. Son un discurso de identidad $y$, al mismo tiempo, un discurso sobre el cambio ya que pueden reflejar las mutaciones sufridas por dicha comunidad.

El cambio se ha detectado en forma de versiones y variantes textuales más que musicales que, en el caso de las canciones de boda, se refieren a lo que hemos denominado modificaciones. Suponen el grado mínimo de innovación y admiten variaciones en el texto sin que la música cambie o, más frecuentemente, variaciones tanto del texto como de la música en cada interpretación, adaptándose a la estructura literaria y musical que caracteriza a cada tipo de canto. La modificación no siempre es considerada como cambio por los propios usuarios, puesto que recae sobre un repertorio al que se exige un grado de variación en cada nueva interpretación.

1 John BLACKING, «Some problems of theory and method in the study of musical change», Yearbook of the International Folk Music Council (1977), IX. 
Por otra parte, al estudiar el proceso de cambio en los diferentes repertorios locales de la provincia de Guadalajara, analizamos las transformaciones sucedidas en cada fase del proceso musical: en la fase de la creación (en el procedimiento, en el tipo de autores: profesionales, esporádicos, grupos); en la fase de aprendizaje; en la fase de interpretación o práctica musical (performance).

Teniendo en cuenta estos factores, hemos estudiado el proceso de creación y la dinámica del cambio, centrándonos en los repertorios de cada localidad, a partir, fundamentalmente, de los datos que se refieren a todo aquel tema musical del que los informantes recuerdan el nombre de su creador o creadores, o de su introductor, y/o la fecha en la que pasó a formar parte del cancionero local, aunque en pueblos vecinos sea ya considerado tradicional por haber sido olvidados estos hechos. Por tanto, son datos reducidos a una pequeña parte de los cambios reales que se produjeron, limitados por la memoria y por la propia concepción que el informante tiene de lo que significa cambio o variación.

Centrándonos en las canciones de boda, observamos que aparecen dispersas por toda la provincia las rondas y despedidas que se daban a los novios para solemnizar uno de los rituales de paso en la vida del hombre (Fig. 1). Asociados a esta ceremonia, insertos en ella, encontramos dos tipos de canciones diferentes que se desarrollan en un tiempo, un espacio y mediante unos intérpretes también distintos, y que pertenecen a dos secuencias del mismo ritual: la ronda que dan los mozos a los novios la víspera de la boda y la despedida que, normalmente, cantaban las mozas a la novia, durante el banquete de bodas. Ambas toman los motivos y las imágenes del canto de los hechos que se están desarrollando y del estado emocional que produce en los participantes. Una es un canto de adiós - la palabra «despedida» aparece con frecuencia en la denominación de la canción: «despedida de novios»- mientras que en la otra se señala más el aspecto festivo de la boda, al constituirse en una ronda con cantares de jota. Posiblemente sean restos aislados de una misma celebración mucho más completa en otros tiempos.

En el sector noroeste provincial la canción de boda tiene una tonada particular, específica de estos acontecimientos, que la distingue de cualquier otra interpretada en la localidad. El «Cantar para la novia» o «Despedida de novios» lo hemos recogido en los siguientes pueblos: 


\begin{tabular}{|c|c|}
\hline Localidad & $\begin{array}{c}\text { N.' estrofas } \\
\text { recogidas }\end{array}$ \\
\hline Bocígano............... & 11 \\
\hline El Espinar $(\mathrm{I}) \ldots \ldots \ldots \ldots \ldots \ldots \ldots \ldots$ & 10 \\
\hline El Espinar $(\mathrm{II}) \ldots \ldots \ldots \ldots \ldots \ldots \ldots$ & 30 \\
\hline Cardoso de la Sierra.................. & 30 \\
\hline Colmenar de la Sierra................. & 5 \\
\hline La Huerce.......... & 16 \\
\hline La Mierla................. & 24 \\
\hline San Andrés del Congosto............... & 20 \\
\hline
\end{tabular}

En pueblos serranos como El Cardoso de la Sierra, Colmenar de la Sierra, Bocígano o La Huerce, las despedidas estaban dirigidas especialmente a la novia. Las cantaban varias mozas - sus mejores amigas o aquéllas a las que más les gustaba cantar- el día de la boda en la casa donde se estaba celebrando el convite, que solía ser la de la propia novia, en señal de que abandonaba el estado de soltería, como dicen en uno de los cantares:

\footnotetext{
Ya te vas, amiga nuestra, ya te vas de nuestro bando te echo un pañuelo a la cara, no te despidas llorando.
}

Lo interpretaba un coro de voces unísonas, o a veces formando dos grupos de voces que se alternaban cada dos versos (La Huerce), sin acompañamiento instrumental.

Al pie de la sierra, en lugares como La Mierla y San Andrés del Congosto, el cantar de despedida de novios lo cantaba la ronda - término que, como sabemos, no sólo designa al hecho de rondar, sino también a quienes lo hacen- con los instrumentos que son habituales en ella: guitarra, bandurria, laúd, botella, almirez, etc. Después del convite se celebraba el baile en el que participaban todos los invitados cantando y bailando jotas y seguidillas. En La Huerce a este baile se le denominaba «de redoma» y era la ocasión en que se cantaban seguidillas. No se ejecutan desde la Guerra Civil de 1936 y ya sólo recordaba algunos cantares la informante de más edad: 
1. A la luna de enero te he comparado, no hay luna más clara en todo el año.

2. La calle de la plaza la están arando, de claveles y rosas la están sembrando.
3. Al pasar por el puente

de Santa Clara

el anillito de oro se cayó al agua.

4. Al pasar por el puente la de la Victoria tropezó la madrina y cayó la novia.

La segunda seguidilla puede hacer alusión a un ritual, ya desaparecido, extendido por Castilla, en el que se uncía a la pareja de recién casados a un yugo y simulaban que araban las calles como símbolo de unión y fertilidad.

La despedida de los novios es una canción narrativa cuya estructura literaria describe el desarrollo de los hechos desde que la novia va a confesarse hasta el convite, terminando con felicitaciones a los novios, padres, padrinos, invitados, e incluso a las cocineras que colaboraban de forma importante en dar riqueza a la fiesta. Su interpretación estaba revestida de cierta solemnidad emotiva. Aunque es frecuente que el texto de la canción se ajuste a las circunstancias específicas de cada pareja, hay una serie de aspectos que siempre aparecen:

- Saludo y petición de licencia para cantar a la novia.

- Descripción detallada de las diferentes secuencias del ritual de la boda (constituye en esta zona el núcleo central de la canción).

- Piropos y vivas a los novios,padres, padrinos, cura y cocineras, etc.

- Consejos y advertencias a los novios (que se cuiden mutuamente, que no olviden a sus padres...).

- Manifestación del significado de segregación del grupo de las mozas que ha supuesto la ceremonia de la boda ${ }^{2}$.

- Despedidas.

El cantar de El Cardoso de la Sierra es el que mejor describe la secuencia de hechos del día de la boda, aunque no en el orden en el que realmente se desarrollan:

2 Con frecuencia aparece la imagen del llanto de la novia en esta estrofa. Giovanni ProfeTA, en su trabajo Canti nuziali nel folklore italiano (Firenze: Leo S. Olschki ed., 1965), habla de la presencia del llanto de la esposa en los cantos nupciales de gran parte de Europa, lo que hace pensar que constituía una secuencia tradicional del rito (pp. 223 y ss.). Para A. Van Gennep, estas lágrimas pueden ser sinceras con frecuencia, pero también la expresión de una costumbre, una ficción. 
1. Examen de conciencia, la víspera, por la noche.

2. Confesión, a primera hora de la mañana.

3. La bendición de los padres al salir de su casa para la Iglesia.

4. Espera en el portalillo de la Iglesia a que salga el señor cura a recibirlos.

5. Casamiento (declaración, entrega de anillos y arras).

6. Coplas en las que se pone de manifiesto el contraste entre subir soltera a la Iglesia y volver a bajar, ya casada, a la casa.

7. Toma de agua bendita, al entrar en la Iglesia.

8. Llegada al altar.

9. Acto de cubrir con velo a los esposos y su significado de unión para siempre.

10. Comunión.

De esta secuencia, los cantares que se repiten con más frecuencia en todos los pueblos son los referidos al punto 3,6-aparecen también en los cantos de boda de otros pueblos de Europa ${ }^{3}-, 8$ y 9.

La melodía del cantar del Cardoso es la siguiente:

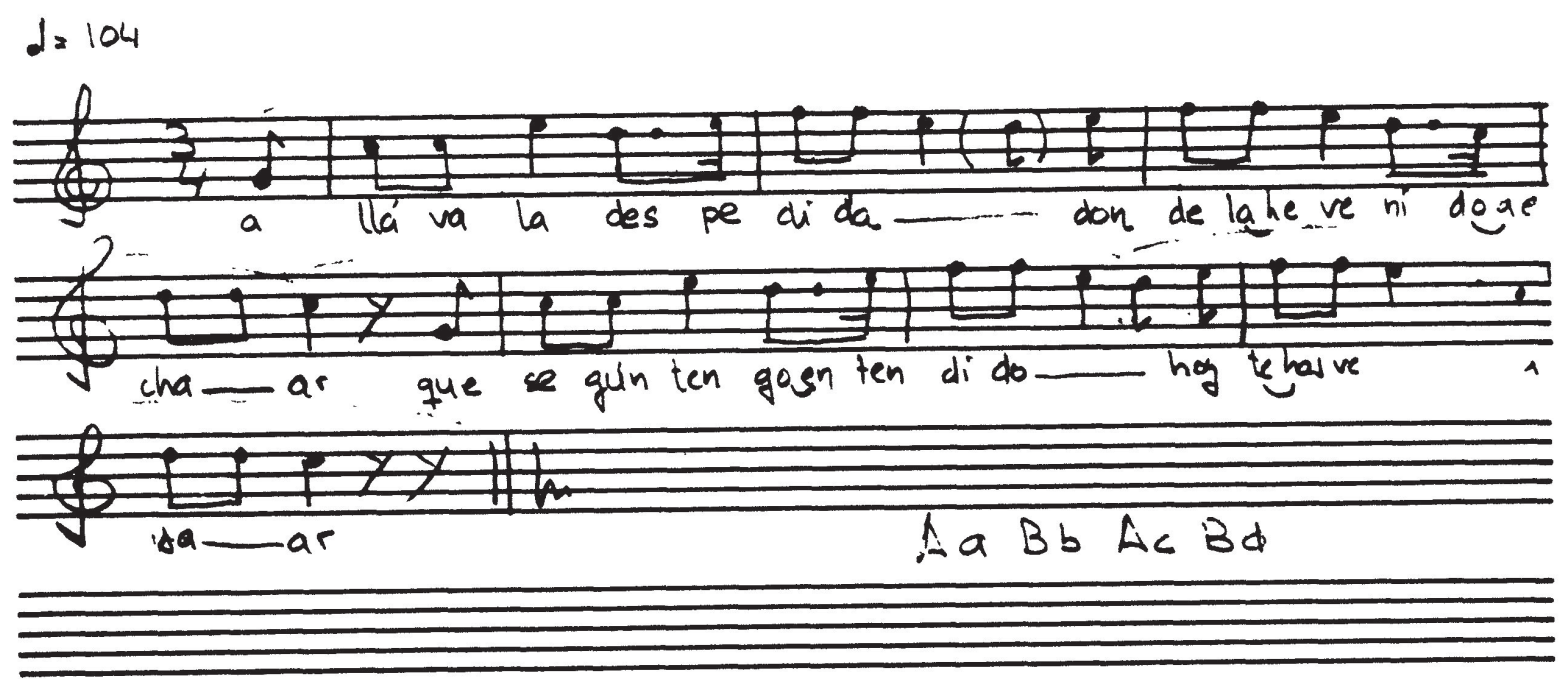

[Partitura núm. 1]

3 Giovanni ProfetA, op. cit. Parte II, cap. I, pp. 181-211. 
1. Allá va la despedida donde la he venido a echar que según tengo entendido hoy te has venido a casar.

2. Tengan ustés buenas noches padres y madres de novios. Tengan ustés buenas noches, buenas las tengamos todos.

3. Estarás toda la noche en un continuo desvelo saminando tu conciencia, todas tus culpas y yerros.

4. A la mañanita irás de mañanita a la iglesia a confesar tus pecados y a mudar de vida nueva.

5. A la mañana la novia, al tiempo de levantarse, pondrá el pensamiento en Dios para ir a confesarse.

6. Te volviste a tu casa con contento y alegría y delante de tus padres te postraste de rodillas.

7. Si tus padres son gustosos la bendición te echarán y cogerás el camino para irte a casar.

8. La bendición de Dios Padre, la bendición de Dios Hijo, la del Espíritu Santo será contigo y conmigo.

9. Ya te fuiste a la iglesia $y$ antes de entrar en la misa ya te estarás esperando a que el cura se revista.
10. Ya que se revista el cura te preguntará primero que si quieres a tu esposo, a tu querido y tu dueño.

11. Tu respondiste que sí, que te mantienes en ello y si en ello te mantienes del cielo te venga premio.

12. Ya que alargaste el dedo para ponerte el anillo, podrás entender en esto que estás sujeta al marido.

13. Ya que te pone el anillo, ya que te entrega las arras, estos son los dos testigos como ya quedas casada.

14. Subiste a la iglesia arriba pisando rosas y flores, bajaste la iglesia abajo al lado de tus amores.

15. Subiste la iglesia arriba pisando rosas y lirios, bajaste la iglesia abajo al lado de tu marido.

16. A la que entras en la iglesia entras con el pie derecho y tomas agua bendita solamente con dos dedos.

17. Ya que llegaste al altar te mostraste de rodillas con la corona en la mano pidiéndole a Dios albricias.

18. Ya que os ponen el velo sobre el hombro y la cabeza, os dan a entender en esto que os aguantéis las flaquezas. 
19. Ya que os dan la comunión, que es un manjar verdadero, que quien lo recibe en gracia derechito se va al cielo.

20. A ti te digo (Fulano) que no la des un sentir, que la han tenido sus padres guardadita para ti.

21. A ti te digo (Fulano) que no la des mala vida, que la han tenido sus padres en el corazón metida.

22. A ti te digo (Fulano) que no la pases el río, no la des pan de centeno, que ella lo come de trigo.

23. Ya te vas amiga nuestra, ya te vas de nuestro bando. te echo un pañuelo en la cara, no te despidas llorando.

24. Ya te vas amiga nuestra. ya te vas amiga mía. Ya te vas de nuestro bando para la otra compañía.
25. Las señoras cocineras no las tengo yo en olvido que han asistido a la mesa lo mejor que hallan [sic] podido.

26. La madrina es una rosa y el padrino es un clavel y la novia es un espejo y el novio se mira en él.

27. Las señoras cocineras no las tengo yo olvidadas, que han asistido a la mesa como mujeres honradas.

28. Despedidas vienen dando allá por la soledad. Despedidas vienen dando y a tu puerta llegan ya.

29. Despedidas a la rosa, despedidas al clavel, despedidas al lucero que sale al amanecer.

30. Despedidas a la rosa despedidas a la palma, despedidas al lucero que sale al rayar el alba.

Aunque en algunos lugares parece ser que se conocía un único texto, en otros se creaban variantes sobre un modelo para cada ocasión que, al interpretarse en grupo, tras varios ensayos, dejaban poco lugar a la improvisación. Encontramos un testimonio de cómo se sustituyen estos cantos en uno de los cuadernos en los que las mozas escribían su repertorio, localizado en El Espinar, pedanía de Campillo de Ranas. Nuestros informantes no conocían la melodía que acompañaba a estos textos que se habían escrito para sendas bodas del vecino pueblo de Majaelrayo. El primero, que parece un fragmento de un cantar más largo, lleva por título Cantar para la novia: 
1. Aunque te vas forastera a tus padres mira bien que les ha costado mucho de verte como te ven.

2. Porque te vas a casar no lleves pena ninguna, que te mueves entre gente tan buena como la tuya.

3. Arrodíllate, arrodíllate, ya te habrás arrodillado, que te echen la bendición los padres que te han criado.

4. Corta niña un ramo de la verde oliva, vete despidiendo de éstas tus amigas.

5. Qué buena mocita está la compañera, señores. Qué buena mocita está, parece un ramo de flores.
6. No te olvides de este hogar ni la cama que has dormido, y a éstos tus queridos padres no los eches en olvido.

7. Salga la madre del novio un pasito más alante a recibir a su hijo y a reconocer a su nuera.

8. Viva la novia y el novio compañero y compañera, todo el acompañamiento y también las cocineras.

9. Ya recogen los cuchillos, ya se limpian los manteles, y si alguna falta ha habido entre nosotros se quede.

10. Qué bien parece la cama, mejor parece la colcha, pero no la estrenarás esta noche con tu esposa.

En esta composición se hace especial hincapié en la segregación de la novia de su familia de origen, instándola a que no olvide a sus padres y aceptando la bendición paterna -estrofas una, tres y seis- y en la integración en una nueva familia - estrofas dos y siete- así como señala también la segregación del grupo de solteras -estrofa número cuatro- La última cuarteta alude a un antiguo ritual según el cual los novios no dormían juntos el día de la boda, ritual que también se extendía entre los judíos ${ }^{4}$.

El siguiente cantar: Casorio para una novia, más completo, está escrito unas páginas más adelante.

1. Empiezo en nombre de Dios a cantar mis compañeras, con licencia de su esposo y señores de la mesa.
2. Comienza el nombre de Dios como costumbre de vida el cantar cuando se casan cualquier hija de vecina.

4 Ver Manuel Alvar, Cantos de boda judeo-españoles (Madrid: CSIC, 1971), p. 35. 
3. ¿Qué mesas tan adornadas aquí al presente encontramos! ¡Qué mesas tan adornadas y todos tan cortesanos!

4. Dios bendiga los manjares que hay en esta mesa honrada. Dios bendiga los manjares el pan, el vino y el agua.

5. Soltera fuistes a misa, soltera de tu albedrío, y ahora ya estás casada y sujeta a tu marido.

6. Por un sí que dio la novia a la puerta de la Iglesia; por un sí que dio la novia, entró libre y salió presa.

7. A la puerta de la Iglesia llegásteis a recibir sacramentos que a los hombres se les da «pa» ser feliz.

8. Qué contento vendrás ya que te la dieron por tuya; tres veces dijo que sí delante del señor cura.

9. El cura que te ha casado en la Iglesia de este pueblo, Dios quiera que le veamos todos juntos en el cielo.

10. Ya te has venido a tu casa con el acompañamiento, te han dado la enhorabuena con alegría y contento.

11. A estos señores novios les damos la enhorabuena. Que se gocen muchos años y todo para bien sea.
12. A los padres de los novios les damos la enhorabuena. Como han visto a estos casados a todos los demás vean.

13. A los padres de los novios, los que aquí no se han hallado, no les echen en olvido, porque Dios les ha llamado.

14. A los hermanos y hermanas del señor novio y la novia, Dios les dé salud y gracia, en todo mucha victoria.

15. Qué mancebo tan hermoso, señora, entró en tu jardín, y como flor más hermosa, señora, te escogió a ti.

16. Qué fino es el paño puro que está hechado (sic) en guarnición.

Más finos son los amores que salen del corazón.

17. Son estos señores novios como la flor del corral (sic) que no hay claveles ni rosas con que poder comparar.

18. Bien sabéis noble señora lo que en la iglesia os han dicho: que sirvas a Dios primero y después a tu marido.

19. La madrina es una rosa, el padrino es un clavel y la novia es un espejo y el novio se mira en él.

20. No te digo que eres rosa ni tampoco eres clavel, sino que eres carne humana y polvo te has de volver. 
21. Bien parece el sacerdote en esta mesa a comer, como el clavel y la rosa al tiempo de florecer.

22. Las señoras cocineras no las traemos olvidadas. Servirán bien a la mesa como mujeres honradas.

23. Los señores forasteros, juntos con los del lugar, que a estos señores novios han venido a acompañar.

24. A los señores mancebos les tenemos que cantar, el regalo pa la novia no se les vaya a olvidar.

25. Y también a los mocitos no traemos olvidados, correrán muy bien el gallo, no les ganen los casados.
26. Ya se despide la novia de todas sus compañeras. Ya se despide la novia y también se ausenta de ellas.

27. Quédate con Dios, adiós, que te vas de nuestro bando. Ponte un pañuelo en los ojos, no te despidas llorando.

28. Lo mismo digo a tu esposo de todos sus compañeros, porque los tiene a comer, también se despide de ellos.

29. Mis compañeros me dicen que te eche la despedida; quédate con Dios, adiós. Adiós compañera mía.

30. Quédate con Dios, adiós ramo de jardín florido. Quédate con Dios, adiós que te vas con tu marido.

Esta segunda versión del canto de bodas de El Espinar se recrea más en la enumeración de los convidados al convite, los piropos a los novios y padrinos o en la descripción del ritual de la boda, lo que nos puede indicar que las circunstancias de esta pareja de novios eran diferentes a las que rodeaban a la pareja para la que fue escrita la anterior composición.

El tema más reciente de entre los recopilados —el de La Mierlase escribió para ser cantado durante el convite de la boda de un familiar del compositor-intérprete del texto. El resto de las despedidas de novios se interpretaron por última vez a finales de los años cincuenta o primeros de los sesenta. La gran emigración producida durante esos años ha sido la causa de que no se celebren matrimonios en los pueblos desde entonces.

En el de La Mierla se mezclan estrofas tradicionales con otras de nueva creación que aluden tanto a la víspera como al día de la boda. Fue compuesto en los primeros años de la década de los setenta y únicamente se percibe su modernidad en el lenguaje empleado, que utiliza abundantes diminutivos y adjetivos. También cambió el lugar en el que 


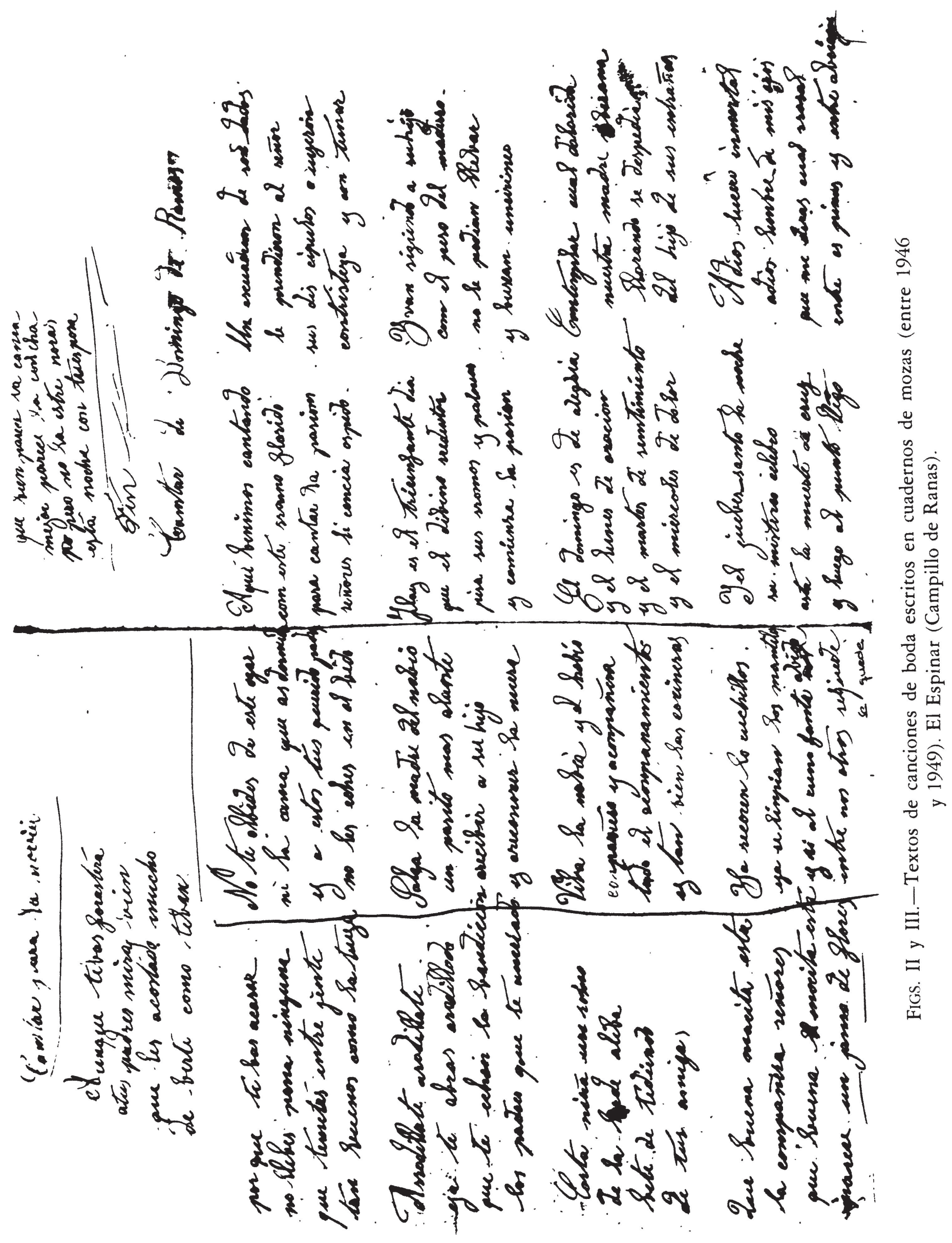



और

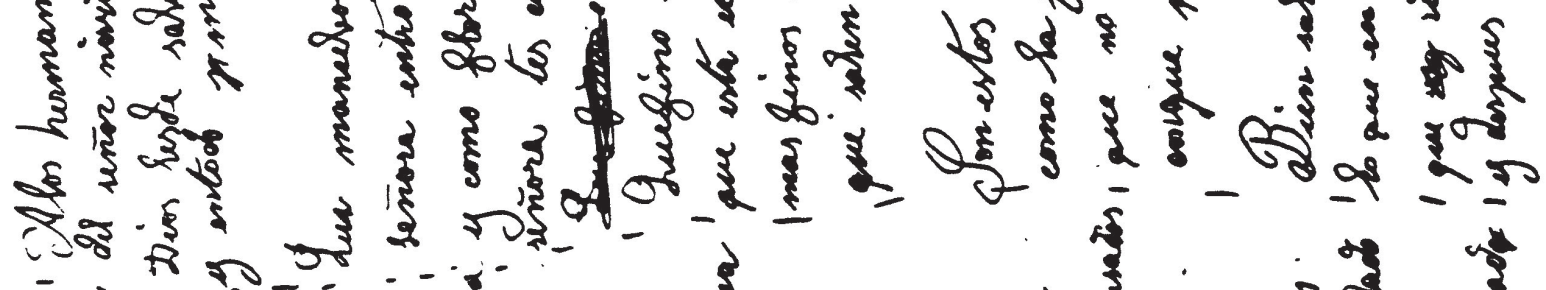

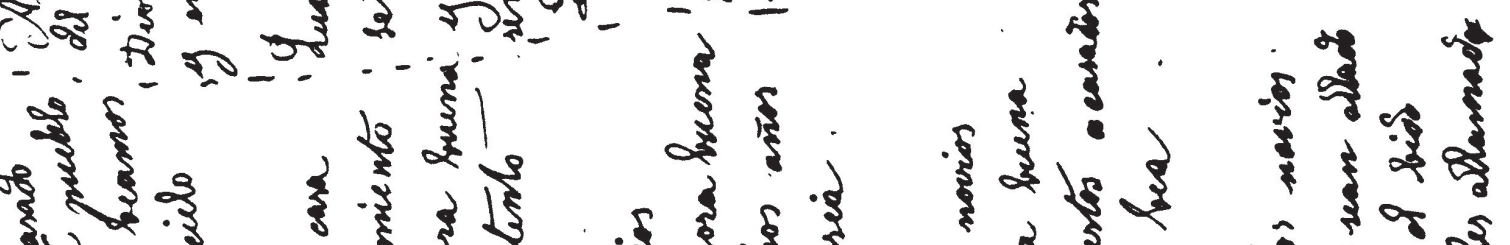
y०क

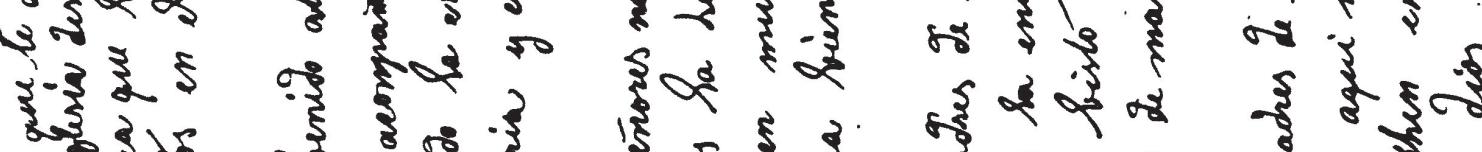
मुर त. की

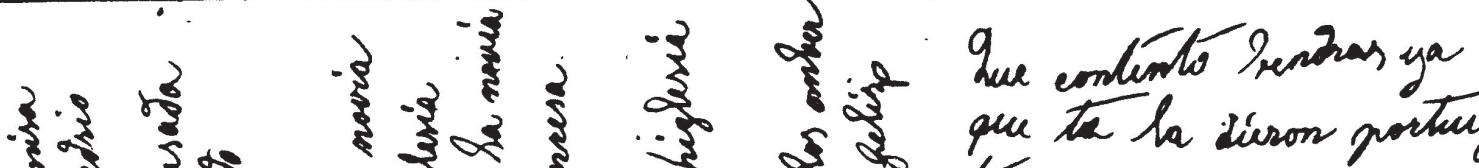
I.

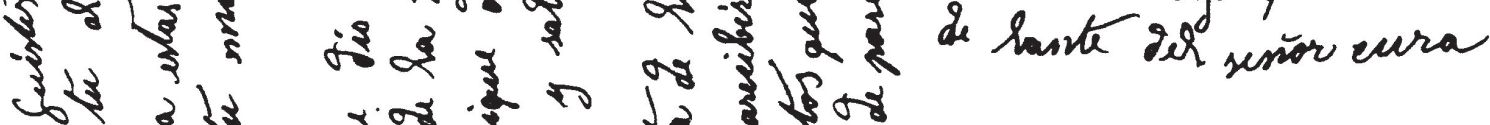
उत्र

(x)

-

If

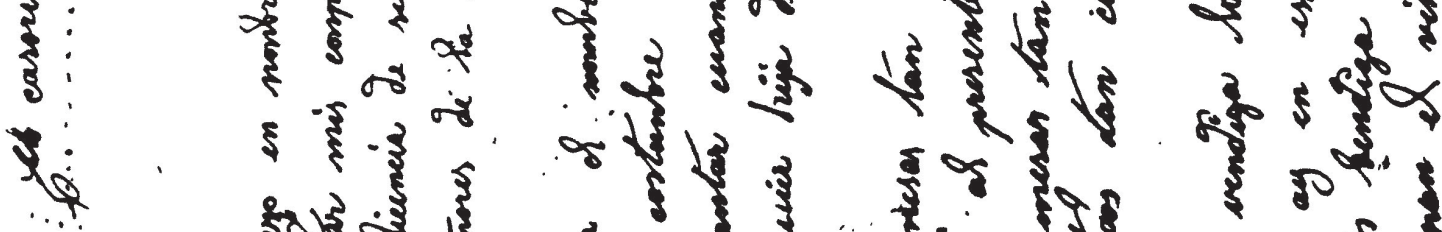
al 0 की 
告 (1)

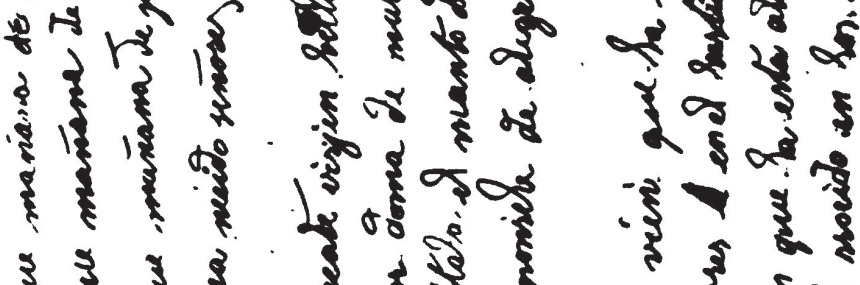

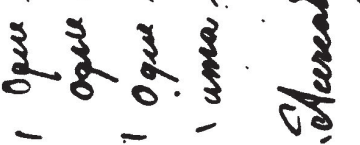

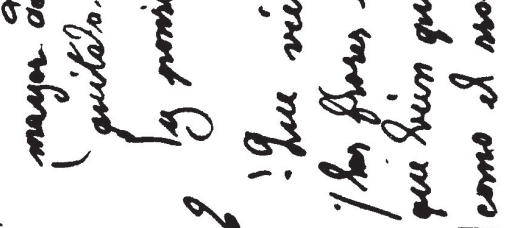

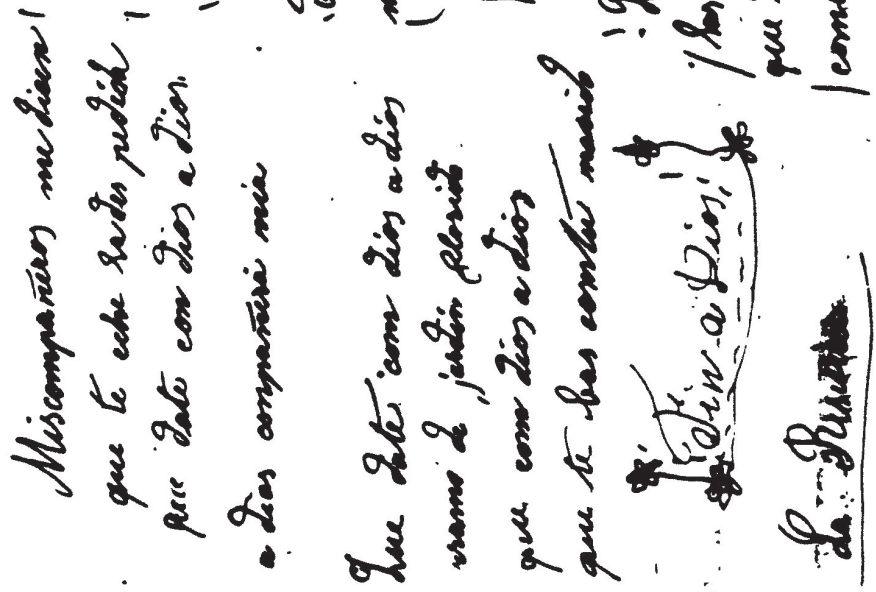

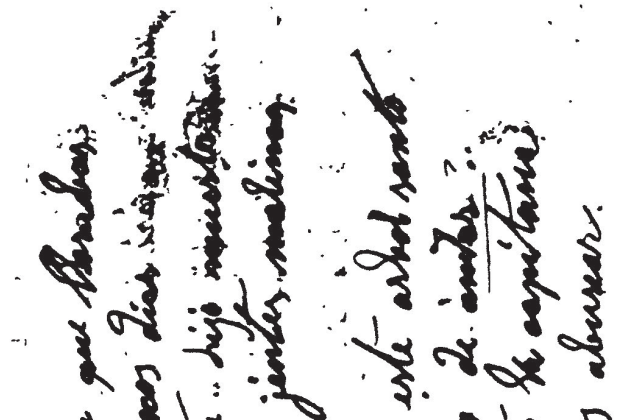

aty

1)

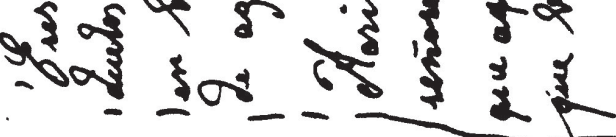

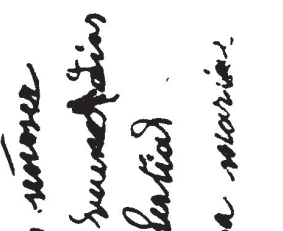
का

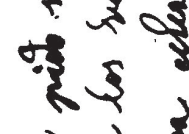

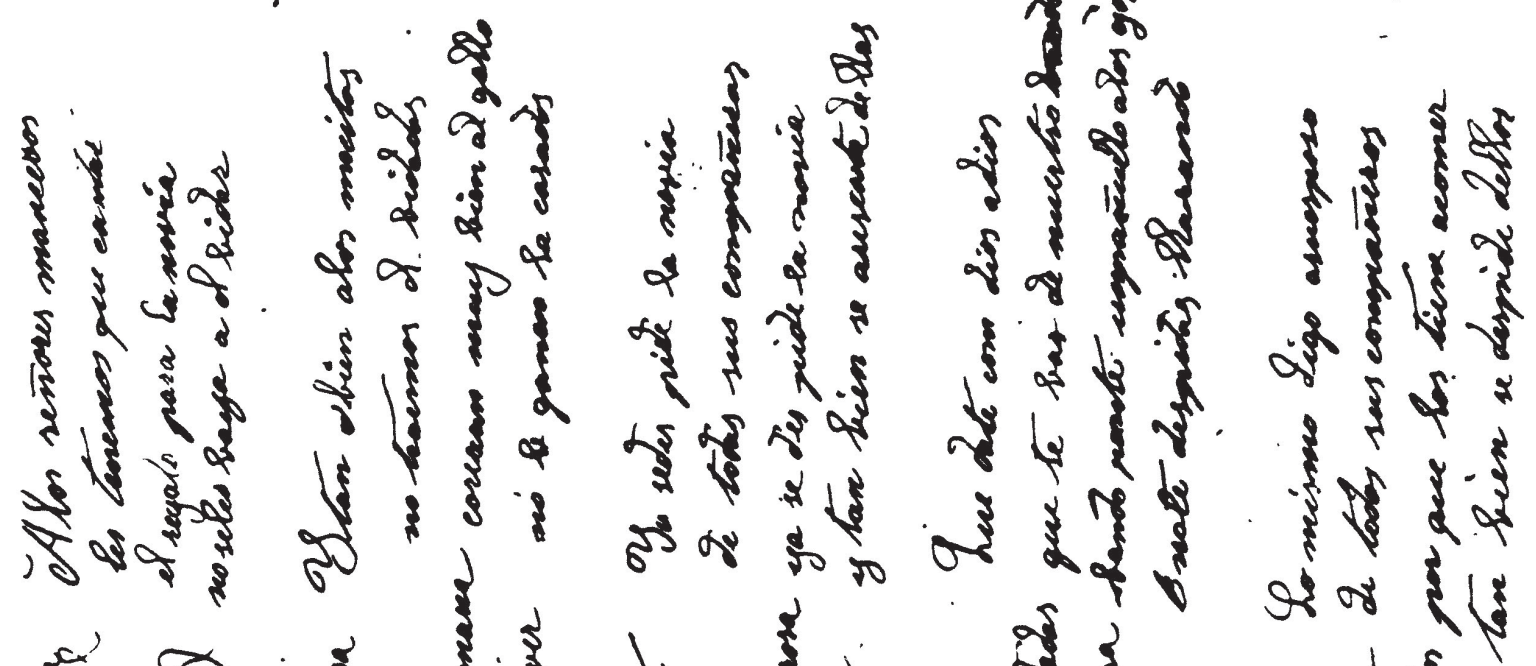

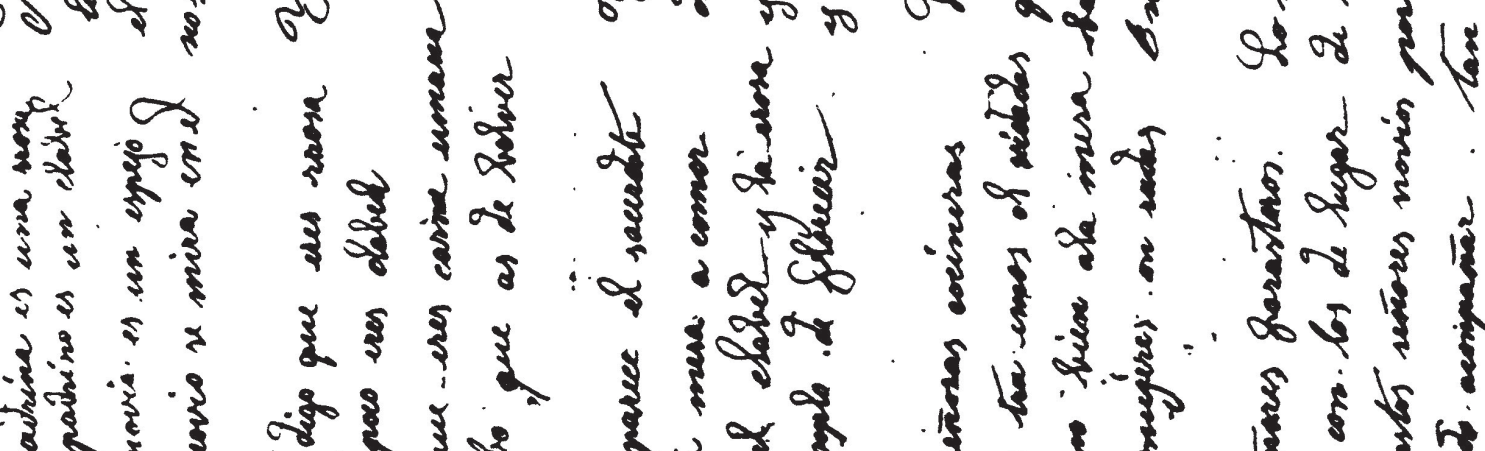

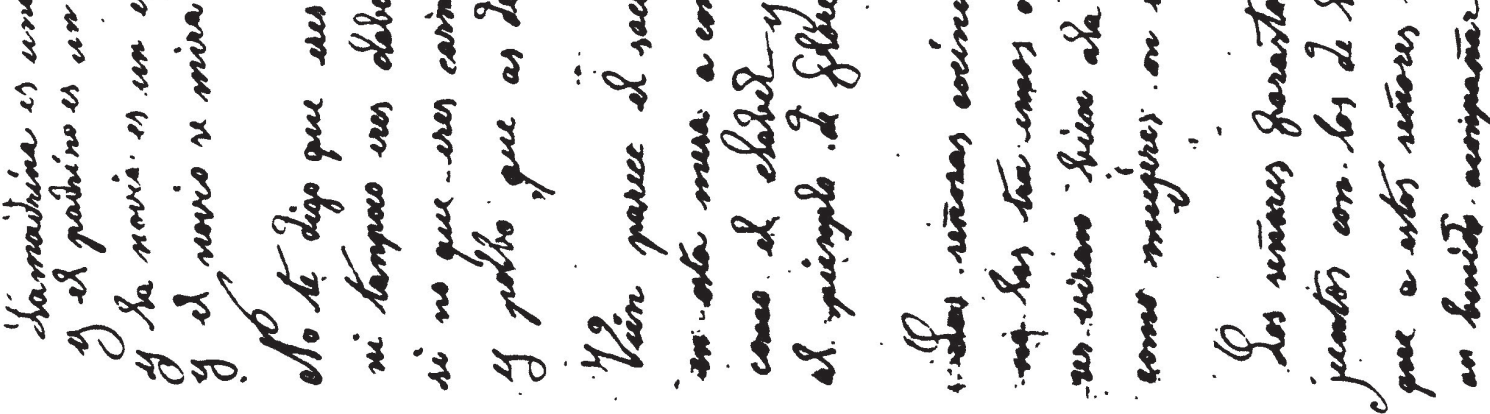


se interpretó que no fue, en este caso, la casa de uno de los novios, sino un restaurante de la ciudad. Como en los casos anteriores, se ha conservado escrito en un cuaderno.

1. A esta puerta hemos llegado con intención de rondar, que según tengo entendido mañana te has de casar.

2. Estarás toda la noche en un continuo desvelo confesando tus pecados, todas tus culpas y celos.

3. Te levantarás mañana y te irás para la iglesia a confesar los pecados y a cumplir la penitencia.

4. Volverás para tu casa y te hincarás de rodillas, te echarán la bendición con inmensas maravillas.

5. Volverás para la iglesia con todo el acompañamiento y te hincarás de rodillas ante el Santo Sacramento.

6. Amada prenda querida no deseo más de ti de que al cura le digas te quiero Joselín, sí.

7. Adiós te dicen los mozos y también tus amiguitas, aquellos que junto a ti compartieron sus alegrías.

8. Adiós, suspiro del alma que me dejas suspirando. Adiós te dice el poeta, tu viejo tío Leandro.
9. Que te da la enhorabuena con estas frases bonitas, que es tradición de los nuestros para Marías y Anitas.

10. Enhorabuena papás, enhorabuena padrinos, a vivir siempre contentos siendo todos felicísimos.

11. Deseamos mucha suerte a este nuevo matrimonio y me despido diciendo ¡viva la novia y el novio!

12. Vivan la novia y el novio y vivan tos los presentes y aquellos que no asistieron por estar lejos y ausentes.

13. Allí te darán las arras, también te dará el anillo y eso te dará a entender que estás sujeta al marido.

14. Subirás la iglesia arriba con los tuyos en silencio. Yo me voy a la tribuna con todos mis compañeros.

15. Delante el altar mayor de rodillas has estado y al alzar a ver a Dios el yugo os han echado.

16. Como la blanca paloma te hemos visto en el altar, al lado de Joselín que espero te sepa amar. 
17. Junto a vosotros están sacerdote y monaguillos y la guardia protectora son allí vuestros padrinos.

18. Te están cantando la misa los mozos y el sacristán, al igual que los mocitos que quieren acompañar.

19. Con abrazos y besitos termina la ceremonia, las mozas besan al novio y yo la beso a la novia.

20. Con vivas para los novios y vivas a los padrinos camina la comitiva a tomar aperitivos.
21. Qué contenta está la novia porque tiene cama nueva. Más contento estará el novio porque va a dormir con ella.

22. La alegría va delante, la pena se queda atrás, de entre las mozas del pueblo una de ellas se nos va.

23. Adiós palomita blanca que te vas de nuestro bando, ponte un pañuelo en la frente, no te despidas llorando.

24. Adiós, lucero del alba. Adiós, almendro florido, que te vas de nuestro bando a vivir con tu marido.

En este caso, lo que más parece interesar al compositor es la descripción de las diferentes partes de la celebración de la boda desde la víspera, aunque también se dedican varias estrofas a dar vivas y la enhorabuena a los novios y otras - cuatro- al hecho de la segregación, una de las cuales - la última - hace referencia al mismo tiempo a la integración en una nueva familia, la del marido.

El resto de las informaciones recogidas en el trabajo de campo se localizan en pueblos de la comarca de Molina - cuya relación con Aragón es notable - y en Algora y Viana de Jadraque, próximos a Sigüenza. En esta zona los mozos dan la ronda a la novia y al novio la víspera de la boda con cantares alusivos a los protagonistas, piropos y alabanzas; o el día de la boda, durante el baile que se organiza después del convite, utilizando una temática más amplia en la que tienen cabida también temas jocosos. La recopilación se efectuó en: 


\begin{tabular}{|c|c|}
\hline Localidad & $\begin{array}{l}\text { N. estrofas } \\
\text { recogidas }\end{array}$ \\
\hline Alcoroches.... & 23 \\
\hline Algora........ & 27 \\
\hline Anquela del Ducado.................... & 6 \\
\hline Checa...$\ldots \ldots \ldots \ldots \ldots \ldots \ldots \ldots \ldots \ldots \ldots \ldots$ & 5 \\
\hline Maranchón............. & 4 \\
\hline Ocentejo....................... & 12 \\
\hline Peralejos de las Truchas................ & 3 \\
\hline Pinilla de Molina..................... & 3 \\
\hline 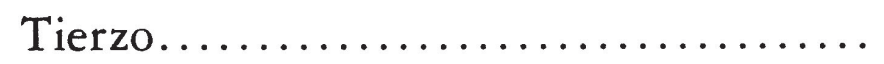 & 4 \\
\hline Viana de Jadraque..................... & 4 \\
\hline Villanueva de Alcorón................. & 26 \\
\hline
\end{tabular}

Estos cantares de ronda, interpretados la mayoría de las veces con el aire de jota característico de otras rondas, tienen un carácter más lírico que narrativo y además no se constituyen como una canción estructurada, por lo que las versiones de cada ronda son mucho más variadas. Cada cantar era interpretado por una persona diferente. Esta puede ser la causa de que, en general, estén muy olvidados y sólo se recuerden las cuartetas que se repetían con más frecuencia.

En los pueblos del Señorío de Molina el ritual que se hacía alrededor del acontecimiento de la boda era largo y complejo. La primera ronda tenía lugar la víspera de la segunda amonestación — se llamaba «dar la segunda»- que siempre era en sábado. La ronda iba a casa de la novia y después a la del novio. Tras escuchar los cantares, la novia invitaba a tortas y cañamones y el novio, por su parte, repartía un puro a cada mozo además de los cañamones y el vino. Si el mozo era forastero estaba obligado a pagar «el piso» (lo último que se pagó fueron 200 pesetas en la década de los sesenta) y con ello hacían una merienda. La ronda y los convites volvían a repetirse la víspera de la boda - la «noche del tálamo»- y era frecuente que después de la ronda se hiciera baile.

El día de la boda «se daba música» a los novios al tiempo que se les acompañaba a la iglesia. Acabada la ceremonia, que se celebraba temprano (a las diez de la mañana), se ofrecía un refresco a los invitados: chocolate, torta y bebida y, a medio día, la comida. Terminada ésta, marchaban todos a las eras del pueblo donde se repartían las tortas y se hacía la «carrera de la paletilla». Las tortas, de gran tamaño, las 
llevaban la madrina y la novia. La de la madrina se repartía entre las casadas y la de la novia entre las mozas.

En la «carrera de la paletilla» participaban todos los mozos que querían. Consistía en lo siguiente: el novio o el novio y el padrino sostenían una paletilla de cordero en alto y los mozos, de dos en dos, competían en una carrera desde el punto señalado hasta el lugar donde estaba el novio con la paletilla. El primero que llegase competía con otro mozo y así se iban eliminando. El que ganaba se quedaba con la paletilla. Una vez de vuelta al pueblo se celebraba el baile.

En Alcoroches, al día siguiente se hacía el «lavatorio». Los mozos iban a buscar a los novios y les tiznaban en las eras, al mismo tiempo que lo hacían entre ellos terminando todos en el río, remojados.

Los cantares de ronda de boda se hacían específicamente para cada circunstancia, aunque muchos de ellos se repetían en todos los pueblos. Se trata de cuartetas octosilábicas asonantadas sueltas, excepto en el caso de Algora en el que se compuso un poema de cuartetas encadenadas. La creación del texto podía ser colectiva cuando se reunían los mozos con dicho fin, o bien individual, encargándose las coplas a alguien del pueblo con especial habilidad reconocida por todos para este menester. Los textos que se crean para adaptarlos a la música tradicional de ronda obedecen, también en este caso, a unas reglas que son constantes y que difieren algo del grupo anterior:

- Las coplas referidas a describir el ritual de la boda son más escasas que en la zona NE. y se refieren principalmente a los puntos 3 , 6,8 y 9 señalados más arriba.

- Las advertencias a los novios (cuidarse y quererse, no olvidar a los padres, etc.) son también habituales.

- La manifestación de la segregación del grupo de los mozos sólo aparece en una localidad:

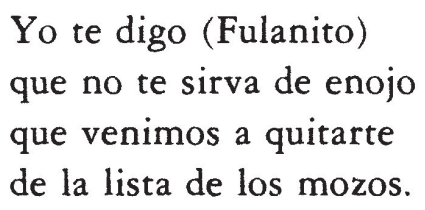

(Villanueva de Alcorón)

- Los piropos a la novia, el novio y los invitados son, en esta comarca, la parte más importante de la ronda. Es frecuente la utilización, como recurso poético, de comparaciones y paralelismos con flores, denominándose esto «echar flores» o con otros elementos cotidianos y familiares para el intérprete: 
En el centro de esta sala tejeré un ramo de flores, las tomaré de una en una para regalo de estos señores.

La primera flor que tomo en mi mano es el romero y la presento orgullosa al señor cura el primero.

La segunda flor del ramo es la verde del endrino y mi mano cariñosa se la ofrece a los padrinos...

(Algora)

Antonio Aragonés Subero nos proporciona algunos datos de la ronda de bodas en la comarca de La Alcarria, en la que participaban casi todos los invitados jóvenes cantando coplas que se referían a las temáticas que hemos aludido:

«La ronda de boda duraba varios días, pues amenizaba la fiesta desde la preparación del pan hasta la visita a los recién casados después de consumado el matrimonio. Había, pues, bailes con cualquier pretexto, y por supuesto acompañar al sacerdote y al novio. Echar las despedidas de solteros; cantares de baile de casados; rondar la habitación de los nuevos esposos en la noche de bodas, etc.» ${ }^{\text {s. }}$.

En Hita las mozas cantaban durante el acto de bendición del padre a la hija que se va a casar con un sentido propiciatorio de bienes. El padre bendice a la hija arrodillada sobre una manta en el portalón de su casa diciendo:

Yo te bendigo, hija mía, con todo mi corazón, y a Dios le pido anhelante pa que os bendiga a los dos.

Un coro de mozas cantaba:

Anda, padre cariñoso, échala la bendición,

5 Antonio Aragones Subero, Danzas, rondas y música popular de Guadalajara (Guadalajara. Diputación Provincial, 1973), p. 177. 


\section{que Primitiva es ahora \\ lo mejor de lo mejor. \\ Cuando has alzado tu mano para trenzar bien la Cruz, has pensado en la mujer que a tu hija dio la luz. \\ Que el Señor tenga tu mano para bendecir con bien, y que la Virgen la traiga salud, paz, pan y miel ${ }^{6}$.}

Este hecho, que asume el aspecto de un rito religioso - el padre se convierte en sacerdote al impartir la bendición a su hija- y familiar - pues tiene lugar en la misma casa paterna- marca el momento en que la mujer deja su familia de origen para pasar a formar una nueva familia y está extendido especialmente en el área en que la familia se rige por un orden patriarcal ?

Al ser cantos que podríamos denominar circunstanciales, su estructura se abre para adaptarse a distintas situaciones. Por eso, junto a esos aspectos fijos ya mencionados, aparecen otros textos que, aunque en ocasiones se repiten con cierta frecuencia, no siempre han persistido y que nos ofrecen datos interesantes sobre lo que suponía el ritual de la boda para los contrayentes. Enla sierra del NE. de la provincia se hacía énfasis en el estado de ánimo de los novios (contento, lágrimas de emoción, recelos, miedo de la novia que se casa para vivir fuera del pueblo...)

\footnotetext{
Aunque te vas forastera a tus padres mira bien que les ha costado mucho de verte como te ven.

Porque te vas a casar no lleves pena ninguna que te metes entre gente tan buena como la tuya.
}

(El Espinar)

\footnotetext{
6 Ibid., p. 178.

7 Profeta analiza el significado de este acto en los rituales de boda italianos. $O p$. cit., p. 194.
} 
Por un sí que dio la novia a la puerta de la Iglesia, por un sí que dio la novia entró libre y salió presa.

(El Espinar)

¡Qué contenta está la novia porque tiene cama nueva! Más contento estará el novio porque va a dormir en ella.

(La Mierla)

No falta tampoco el recuerdo los padres fallecidos, cuando se da esta circunstancia:

Del cielo bajó una carta escrita con hierbabuena que l'ban mandado tus padres por darte la enhorabuena

Del cielo bajó una carta escrita con perejil que l'ban tenido tus padres guardadita para ti.

(San Andrés del Congosto)

En toda la sierra, zona deprimida económicamente, son muy frecuentes los cantares que hacen alusión al banquete de bodas y casi nunca faltan las enhorabuenas o vivas a las «señoras cocineras», lo que demuestra la importancia de esta comida festiva:

¡Qué mesas tan adornadas aquí al presente encontramos! ¡Qué mesas tan adornadas y todos tan cortesanos!

Dios bendiga los manjares que hay en esta mesa honrada. Dios bendiga los manjares, el pan, el vino y el agua.

(El Espinar) 
Las señoras cocineras

no las tengo yo en olvido, que han asistido la mesa

lo mejor que hallan (sic) podido.

(El Cardoso de la Sierra)

El contexto distendido y alegre en que se interpretaban los cantares de ronda en la zona de Molina o durante el baile en la sierra NE. era favorable a una temática más amplia, como podemos percibir a través de unos pocos testimonios. Por ejemplo, encontramos alusiones a las tortas de la boda:

A por la torta venimos, sin la torta no nos vamos, y si no nos dan la torta a la moza nos llevamos.

(Anquela del Ducado)

Si nos has de dar la torta dánosla que tenga picos, para eso nos estás diciendo no te dará en los hocicos.

(Checa)

Salga la madrina, salga, salga, vuelvo a repetir, con un cuchillo en la mano y la torta pa partir.

(Viana de Jadraque)

También al estado de alegría de los novios o al de decepción de los ya casados, así como cantos jocosos alusivos a la vida en el matrimonio, no siempre feliz:

¡Qué contento que estarás que te la dieron por tuya! tres veces dijo que sí delante del señor cura.

(Villanueva de Alcorón) 
Portalillo de la Iglesia

a cuantos harás penar:

unos por haber entrado

y otros por querer entrar.

(Maranchón)

Dicen que casar, casar, yo también me casaría si la vida del casado fuera como el primer día.

(Pinilla de Molina)

Ya te has casado, buen mozo, ya te puedes preparar una vara con un gancho y garrote de verdad

Por si un día la muy bribona te quisiera tirar el gancho l'echas al morro y con el garrote, ¡zas!

(Tierzo)

El acontecimiento celebrado también es muy propicio a las alusiones sexuales:

Esta es la última noche que te quedas de doncella. A eso de la medianoche le pegas fuego a la leña.

(Villanueva de Alcorón)

Ya sé que estás en la cama.

Ya sé que durmiendo no.

Ya sé que estarás diciendo ése que canta es mi amor.

Ya sé que estás en la cama.

$Y$ a sé que durmiendo no.

Ya sé que tendrás la mano donde el pensąmiento yo.

(Anquela del Ducado) 


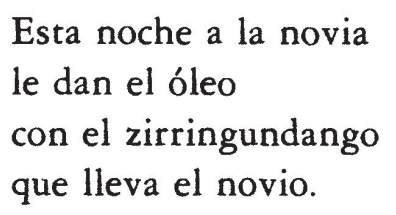

(Peñalver)

o a las circunstancias económicas en las que tiene lugar la boda:

$$
\begin{aligned}
& \text { ¡Ay, amigo Vicente! } \\
& \text { en mal año te has casado } \\
& \text { que van las judías caras } \\
& \text { y el trigo también va caro. }
\end{aligned}
$$

(Checa)

Cada cantar, como el resto de las rondas, se interpretaba individualmente, con acompañamiento de guitarra, laúd, bandurria, a veces violín, botella, hierros y platillos, etc. La estructura métrica de los cantares, como vemos en los ejemplos precedentes, es la cuarteta asonantada y la seguidilla acompañando al baile homónimo. Hay que decir, sin embargo, que las despedidas a la novia y las rondas no se daban a todas las parejas, lo que sin duda reviste de ciertas connotaciones sociales a este tipo de cantares.

Como hemos visto, estos cantos ocasionales, escritos para una determinada circunstancia, se sustituyen unos a otros en una misma localidad, siempre respetando el esquema - literario musical - que los caracteriza. En la zona serrana del noroeste de la provincia, al interpretarse el tema en un contexto más ritualizado, el modelo admite menos variaciones en su interpretación, mientras que en las rondas, donde el ambiente es más distendido, cada cantor puede improvisar en su estilo tanto musical como textualmente en el momento de la interpretación. Las grandes modificaciones son lentas en este tipo de cantos que, al igual que muchos de los que caracterizan a otras rondas, son efímeros y cambiantes por naturaleza.

En conclusión, el proceso de modificación en este tipo de cantos se produce a través de la creación de textos fijados siempre a un patrón tradicional que marca el metro de los versos, la rima y el tema, que son adaptados a una melodía preexistente que a veces también admite variación, como en el caso de las jotas cantadas en rondas y bailes. El cambio, por lo tanto es muy leve. En realidad esta variación es una característica misma de los textos de tradición oral, pero es una variación consciente que se produce en el momento de la composición, 
aunque también está ligada al de la interpretación porque, con frecuencia, es en esta fase cuando se crea, improvisando, sobre todo en las rondas. Es al mismo tiempo una innovación que se produce dentro del sistema musical, que ocasiona un cambio gradual de estilo, pero no se traduce en una alteración en el modelo de relacionarse música y otras facetas de la cultura, puesto que las canciones que presentan estos cambios suelen integrarse en los hechos sociales propios de su clase.

Las modificaciones se difundían entre los intérpretes y usuarios por la práctica musical o mediante ensayos organizados entre los intérpretes, como sucede con las despedidas de boda cantadas por las mozas en el NO. de la provincia. Las versiones de «despedidas» y de rondas creadas ocasionalmente, sustituían a los textos anteriores. Pero mientras que aquellas estrofas más apreciadas tanto por el intérprete como por el destinatario del canto, referidas a aspectos constantes en el ritual de la boda, han tendido a conservarse con escasa variación, las referidas a hechos más específicos de cada circunstancia, por lo general, se han difundido en un espacio de tiempo corto porque respondían a un hecho momentáneo que, al desaparecer, anulaba la razón de ser del cantar que surgió de él.

M. ${ }^{a}$ Asunción LizarazU de Mesa 
A través de una colección concreta de canciones de boda recogidas en la provincia de Guadalajara analizamos la visión del ritual de la boda, de la sociedad que las produce y las admite como propias, y la evolución de su mentalidad, pues son cantos ocasionales que se crean para cada circunstancia específica. Al mismo tiempo se observa la repercusión que los cambios sociales pueden tener en la música. Tanto los textos como los factores que intervienen en las diferentes fases del proceso musical (compositores, intérpretes y audiencia) ponen en evidencia una dinámica de cambio, que, en el caso concreto aquí tratado, consiste en pequeñas modificaciones o variantes tanto textuales como musicales que pueden conducir a cambios de estilo, mientras el repertorio continúa en vigencia, pero también manifiestan cambios más radicales que llegan a sustituir un sistema musical por otro, produciendo la extinción no sólo de repertorios antiguos sino además la transformación del concepto mismo de música y su significación cultural.

Taking as a basis a specific collection of wedding songs compiled in the province of Guadalajara, we analyze the view that wedding rituals inspire in the same society that composed and recognized them as a creation of its own, and furthermore, the change which that society was subject to, as reflected by those occasional songs that were created for the sake of specific circumstances. Consideration is also given to the repercussions that social changes may have on the evolution of music. Both the texts and the different factors that are involved in the different phases of the musical process (composers, interpreters and audience) bring to light a dynamics of change which, in the specific case assessed here, consist of small modifications or variants, both textual and musical, presumably leading to changes in style, while the repertoire continues in force; they manifest, though, more radical modifications that go as far as cause the substitution of a musical system for another, a circumstance that entails not only the disappearance of ancient repertoires but also the transformation of the very concept of music and of its cultural significance. 


\section{APÉNDICE}

Transcripciones musicales, por Pablo Peláez Benítez

Bocígano

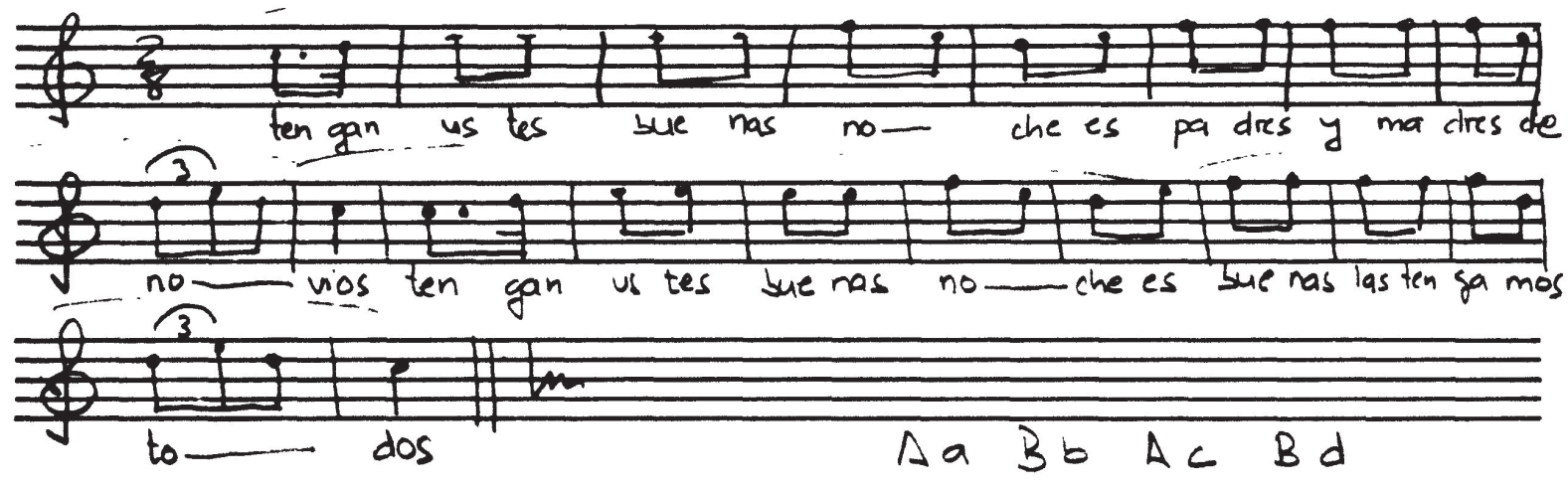

Colmenar de la Sierra

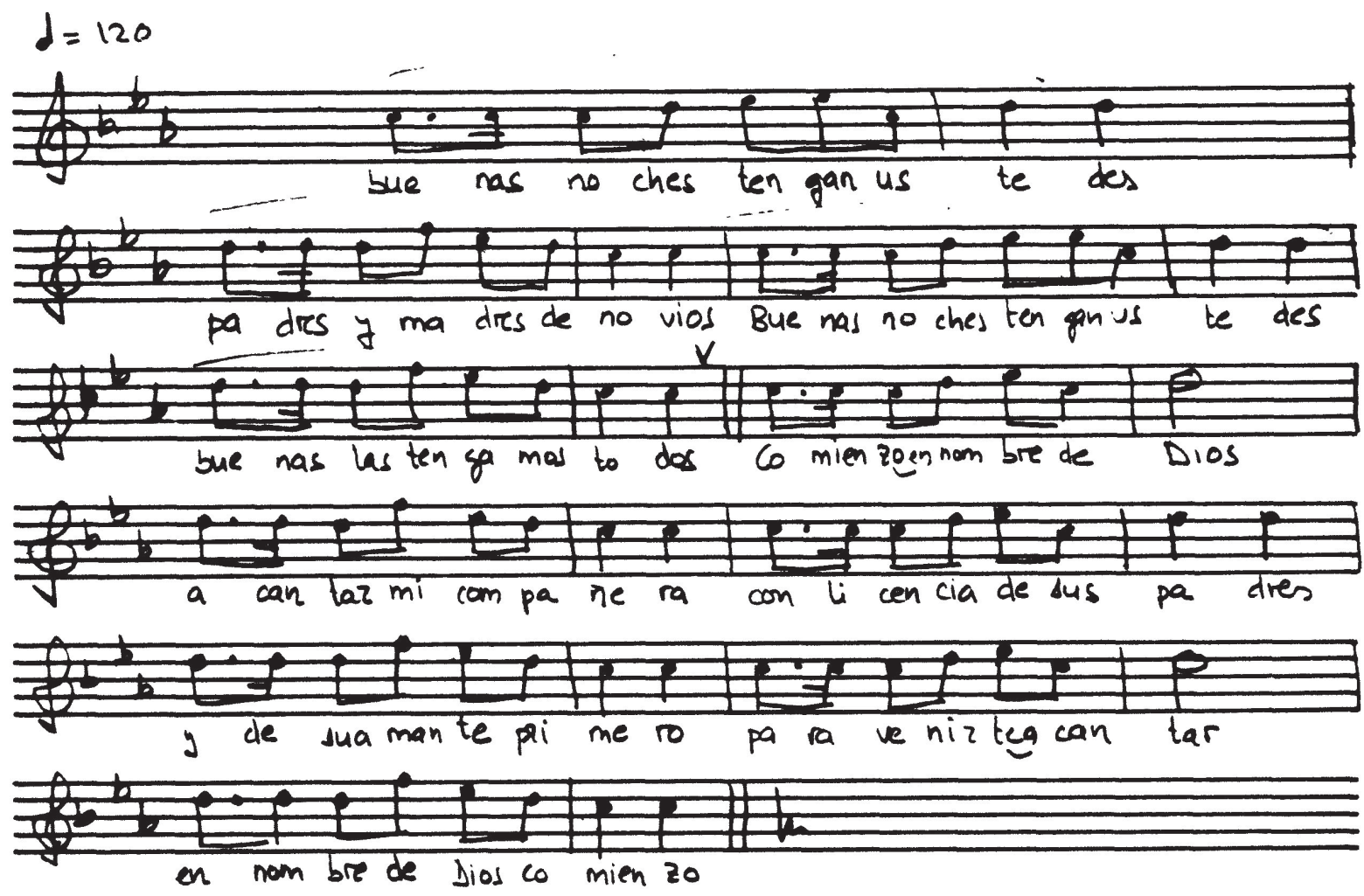




\section{La Huerce}

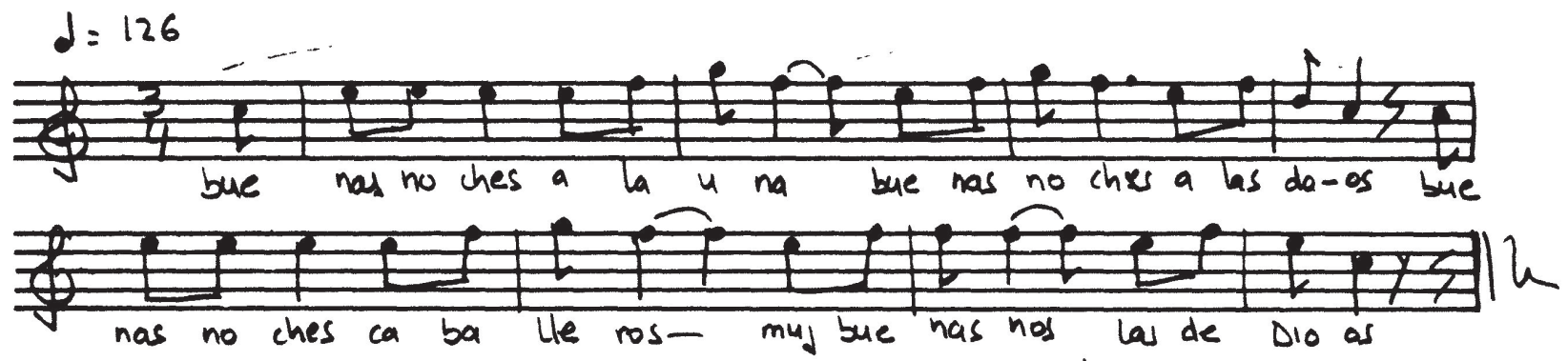

San Andrés del Congosto

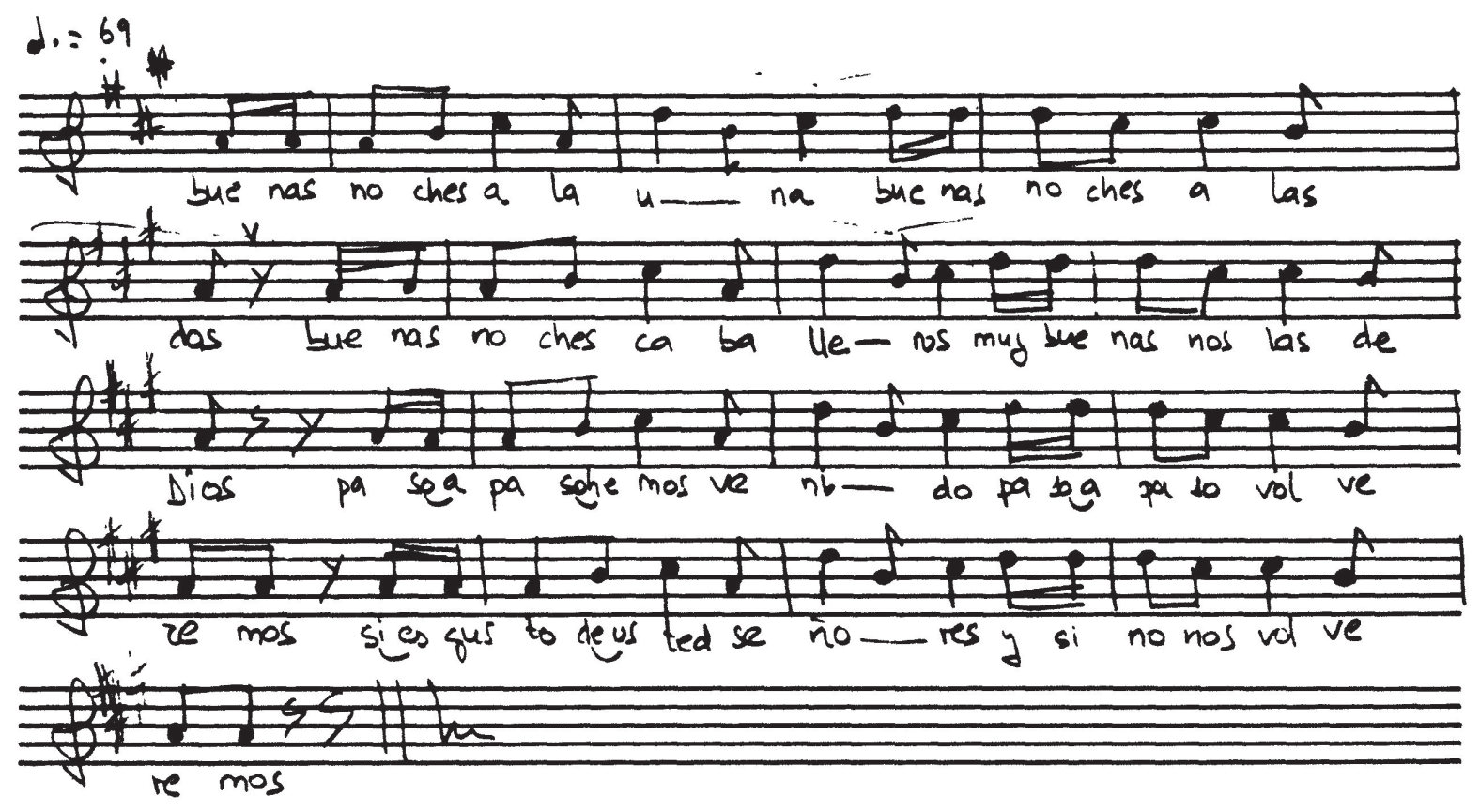


Alcoroches

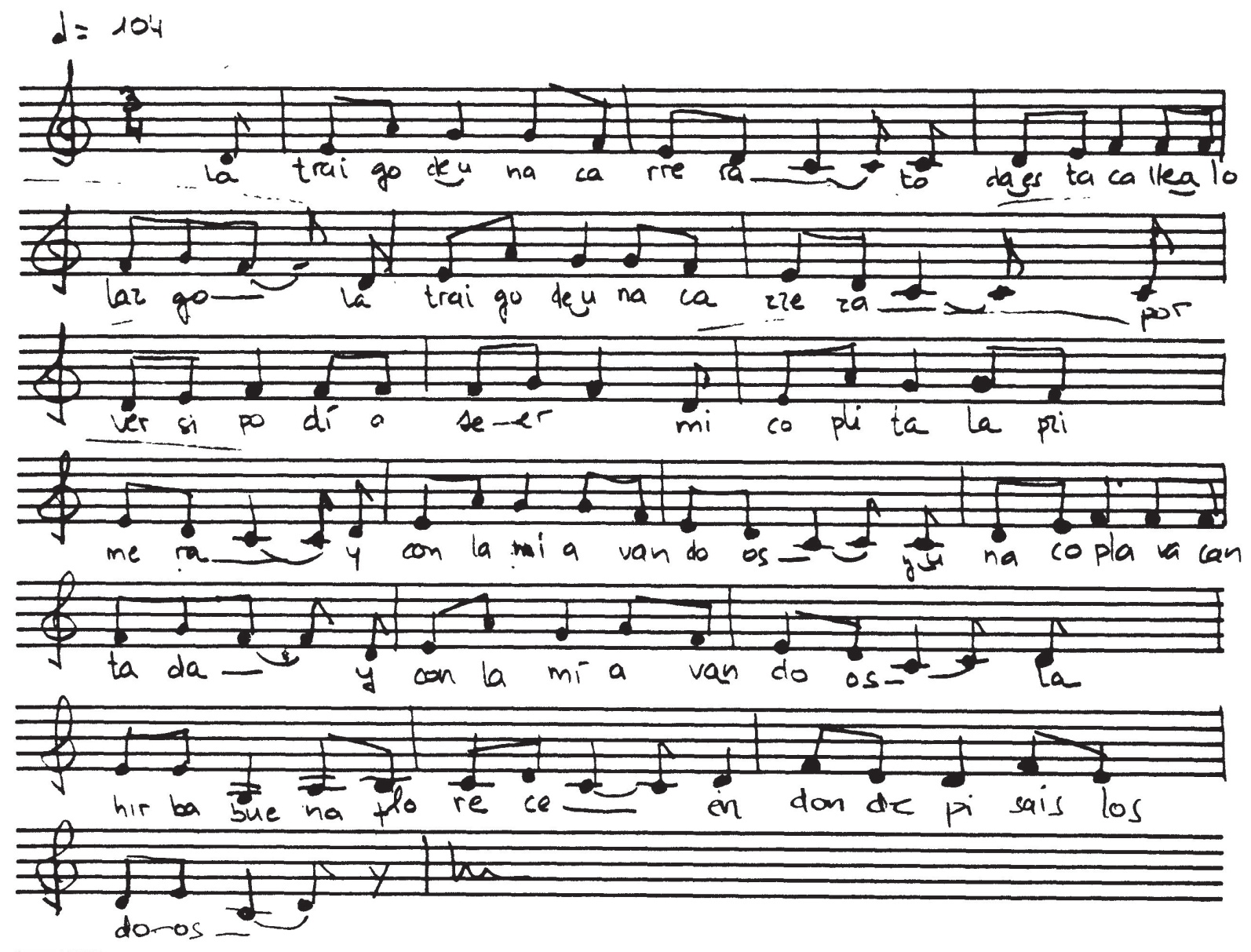

Pinilla de Molina

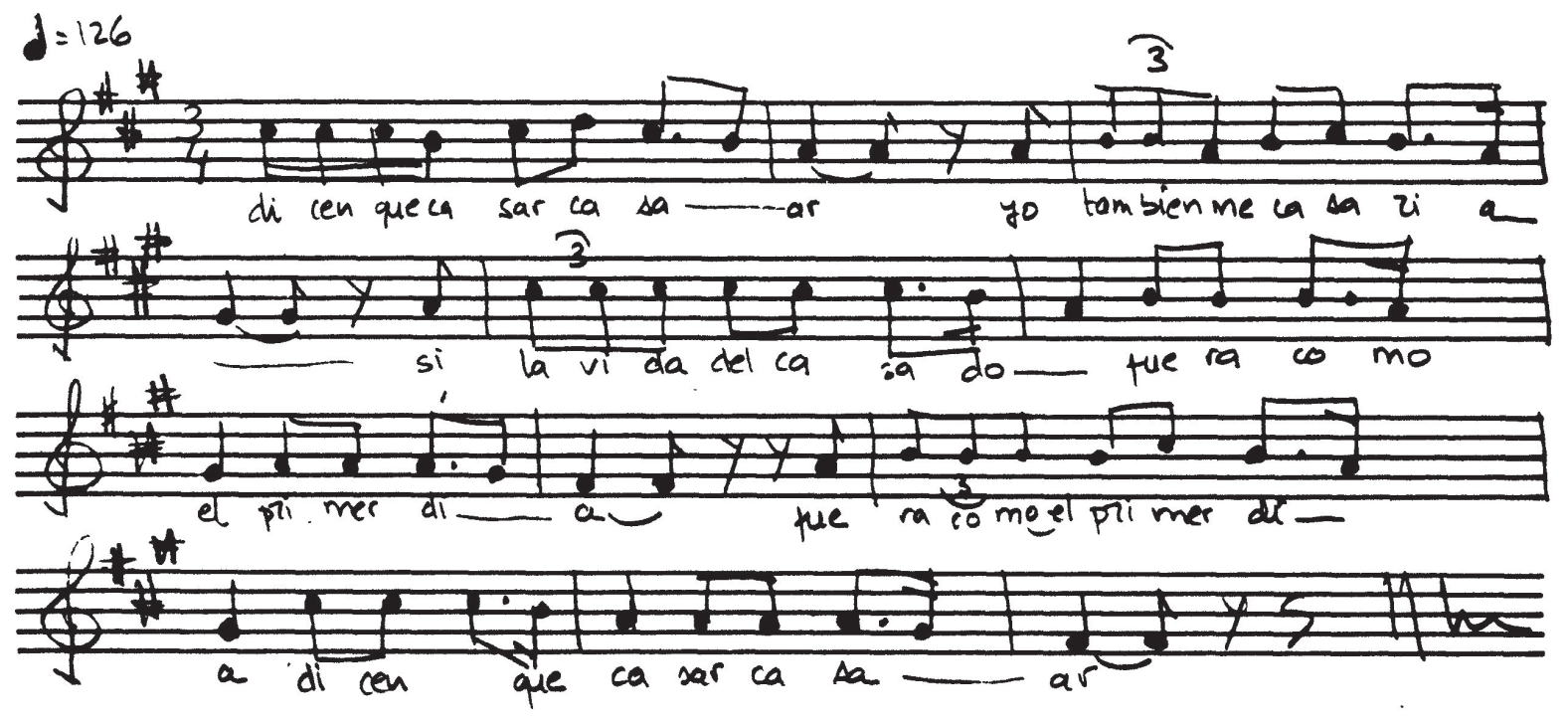




\section{Maranchón}

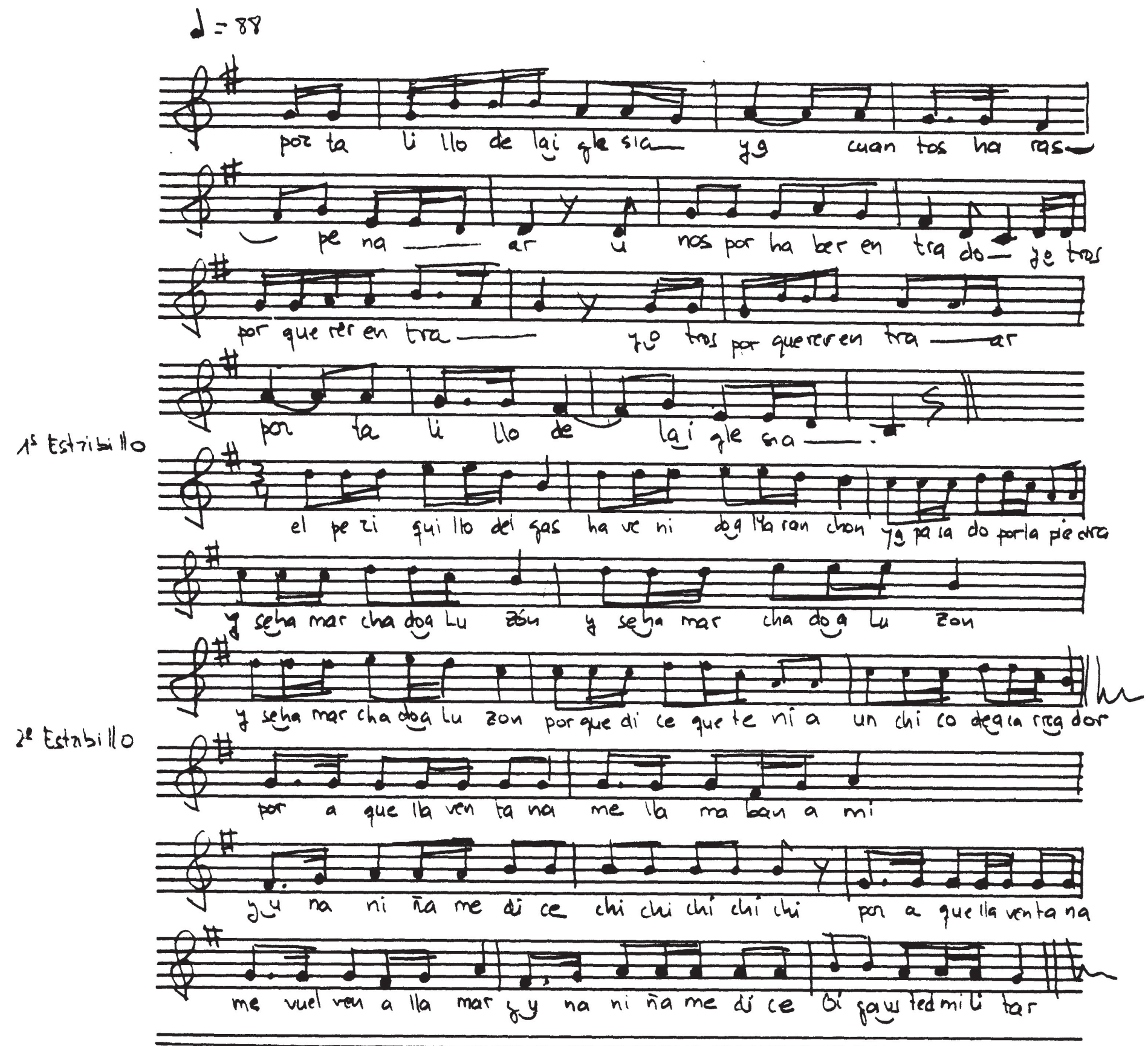


Villanueva de Alcorón

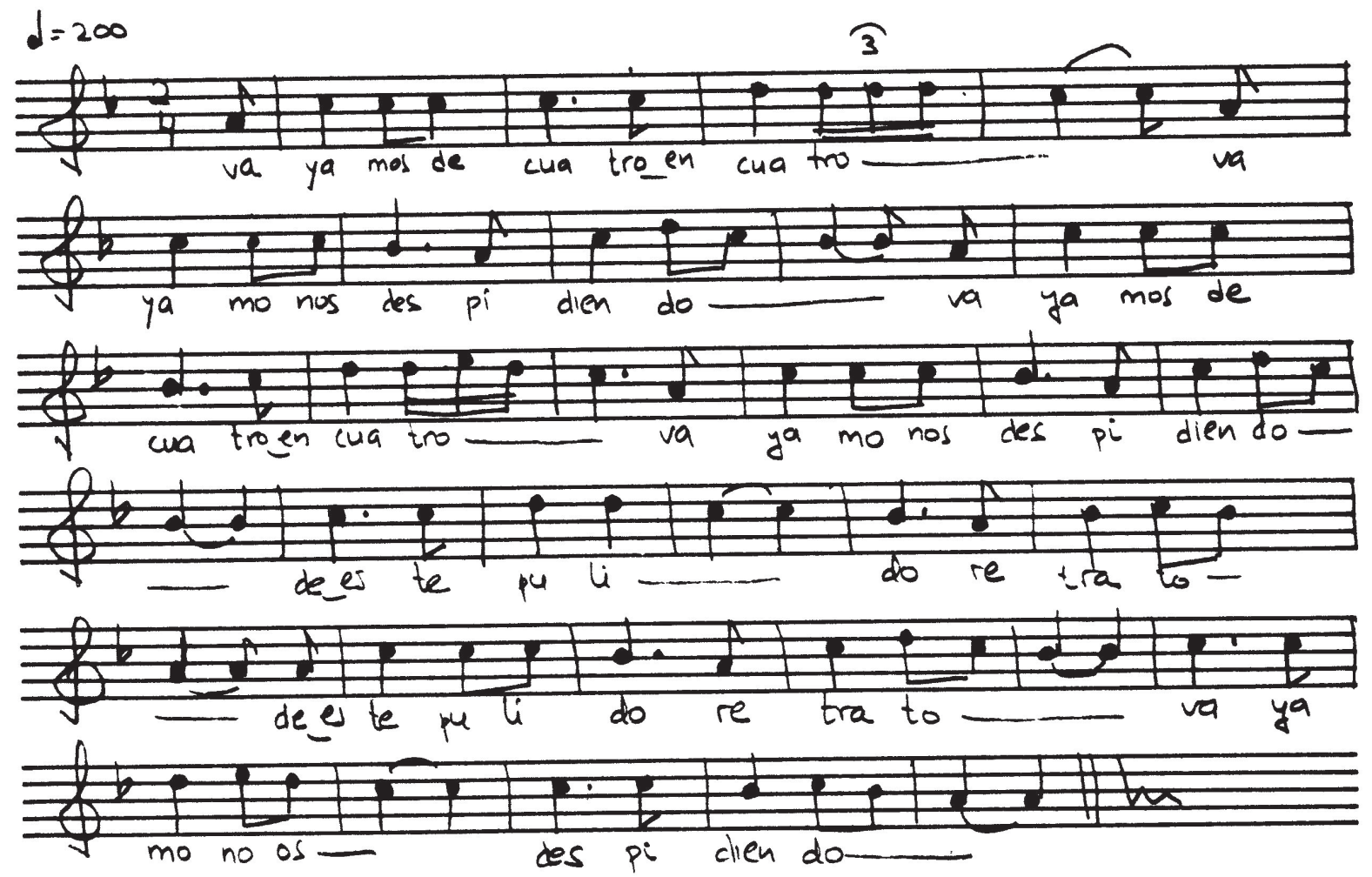

